\title{
THE CHALLENGES OF GLOBALIZATION
}

\author{
Ilija Kajtez and Dragan Gostović ${ }^{1}$ \\ University UNION - Nikola Tesla, \\ Faculty of International Politics and Security, Belgrade
}

$G_{\text {lobalization is a planetary process because the steamroller of the }}$ computer revolution, the expansion of the world market, free circulation of goods and capital make society more and more an interdependent network. Contemporary society is in a deeper division of destiny with rising risks, as well as threats. On the one hand there is such increase of cooperation and connection between countries and nations, and on the other hand many new regional conflicts of wider scale threaten to happen.

The existance of different nations, religions, traditions, interests, monopolies, values and morals is the destiny of all inhabitans of the planet. Globalization is the unavoidable historical course. It is the driving force of the world and all societies are confronted with a challenge of adaptation to the new world order. However, the path of modern society is open and uncertain; it can lead to either unification or fragmentation of the world, cooperation of civilization or conflicts of people.

If the world wants to survive, it must cooperate regardless of many antagonisms, mistrust and military competition of the great powers. The modern world requires much wisdom and good will, concession and understanding in order to build brighter, shared future for all. threats

Key Words: globalization, planetary process, cooperation, conflict,

\section{Globalization - the Conflict and Hope}

$T$ he ones who wisely conclude are deeply right: "So much has happened so quickly that we need new theories to explain the recent past, let alone to shape the opportunities, challenges, and threats of the era that lies ahead." ${ }^{2}$ The famous historian Toynbee noticed that there are some events, which are the symbols of one epoch; globalization is the thing, which determines the spirit of the present time. It reshapes everything that is touched upon, fully changing the nature of the nation-state and the interna-

\footnotetext{
${ }^{1}$ Professor Ilija Kajtez, PhD, Col. Rtd. and Assoc. Professor Dragan Gostović, PhD, Col. Rtd.

${ }^{2}$ Cohen, R. Mihalka, M.: Cooperative security: New Horizons for International Order, The Marshall Centre Papers, No. 3, Garmisch-Partenkirchen 2001, p. III (Preface)
} 
tional order. ${ }^{3}$ That change is not only voluntary, but often dramatic and bloody because of conflicts, destruction and wars. Globalization is subject to misunderstanding and irrationality because it is the imprecise and indefinite concept. It is not a single process, but the composition of multiple processes that are sometimes intertwined, but also in conflict. Some people say that it is the synonym for the 'world without borders'.

Globalization is an extremely complex, dynamic and contradictory social-historical phenomenon, it is "understood as ... establishing of the unique global system....because the cultural, social, economic and political differences are destroyed in the world...However, globalization is often followed by localization, regionalization... religious fundamentalism can be understood as the answer to globalization..." ${ }^{5}$ The initial picture about globalization as the source of peace and progress vanished, giving way to many characteristics of the 'black utopia' which far exceeds Orwell's dark expectations. Richard L. Kugler stresses that globalization is rather understood positively because it was considered that it would bring economic progress and democracy to every corner of the world. However, due to many complex reasons, globalization, unfortunately, creates new divides in the world. Then he claims that democracies become more stable, but in other parts the losers of globalization, who do not know how to react to radical social-historical changes that happen too quickly around them are multiplied. Therefore Kugler concludes: "In this atmosphere of angst and confusion, globalization is nurturing venomous anti-Western ideologies and deeply angry actors - including nihilistic terrorists and menacing countries bent on acquiring WMD systems - that are willing to lash out against Western democracies and others that they blame for their fate. These new threats are merging together in ways that reinforce each other. They also are gaining access to modern information systems and technologies that allow them to inflict violence at very long distances, from one continent to the next."

In the contemporary world there is not only agreement, harmony and peace, but also various competitions, severe conflicts and wars. The future of the world according to some authors, who are more realists than pessimists, does not look bright at all. As already mentioned, Kugler claims that the $21^{\text {st }}$ century, despite globalization or because of it is becoming a dangerous time for living with many challenges and threats like global terrorist networks, wild ethnic wars, destruction of countries, regional violence, the spread of weapons of mass destruction (WMD), and geopolitical rivalry. Some people speak about the $21^{\text {st }}$ century as a "new hundred-year war" - an ugly time of chaos and aggression in many parts of the planet.

Globalization encompasses all: "... international events and networks of the thing". Integration is a planetary process because the steamroller of the computer revolution,

\footnotetext{
3 "The Westphalian concept of the absolute right of states to act as they see fit within their own territories is no longer accepted by liberal democratic states... The concept of state sovereignty cannot be a screen behind which mass violations of human security can take place...", ibid., p. 7

${ }^{4}$ Globalization is the occurence of the complex network of the common connection, which means that our lives are influenced by the decisions and events around us.

${ }^{5}$ Heywood, A.: Politics, Second Edition, originally published by Palgrave Macmillan Ltd. Hampshire, New York, 2002, p. 138

${ }^{6}$ Ham, P.V. Kugler, R.: Western Unity and the Transatlantic Security Challenge, The Marshall Centre Papers, No. 4, Garmisch-Partenkirchen, 2002, p. 42

${ }^{7}$ Held, D. McGrew, A. Goldblatt, D. Perraton, J.: Global Transformation, Politics, Economics and Culture, Policy Press, Cambridge 1999, p. 16
} 
the expansion of the world market, free circulation of goods and capital make society more and more an interdependent network. Contemporary society is in a deeper division of destiny with rising risks, as well as threats. On the one hand there is such increase of cooperation and connection between countries and nations, and on the other hand many new regional conflicts of wider scale threaten to happen. "No single trend, over the past decade, deserves more careful analysis than the remarkable growth of cooperation among the countries of Eurasia and North America." A global order looks to us as the force which moves invisible threads of our everyday life, influences and reshapes the lives of billions of people. Globalization is both the conflict and hope at the same time: "Dramatic social conflicts about globalization - its democratic or repressive, more human and asocial, multipolar and unipolar look - become a new key of understanding of social events ... the ones see globalization as...the objective and spontaneous process, for the others it is exclusively the project of west domination ... the recipients of globalization find exclusively civilization progress ... for the losers it is just destructive force and new curse..." Complex as the world is, turbulent, whirling and contradictory, with many lights and abysses of darkness. Everything is involved in the game, the destinies of billions of people, the fortune of people and hopes of single beings.

Trying to better understand the processes of globalization and integrations we can more easily understand modern conflicts, challenges and threats to the world peace and human security. Does globalization really bring social well-being or a social abyss of inequality, destruction of national and cultural identity of people, and wars between civilizations? Does it support planetary democracy or the authoritarian power of the elite, an order of harmony with nature or result in the irreversible destruction of natural resources? There are more serious and difficult questions about effects of globalization on humanity and the world than sure and unquestionable answers. The thing that is new in the conception of the modern world is that people are not only connected territorially; the end of 'society' as exclusively territorial notion is coming.

\section{The World Always Tended to Cooperate}

The concept of an interconnected world is not historically new. The development of trade routes, such as the Silk Road, as well as the expansion of great religions, civilizations and empires, are historical forms of uniting different worlds. The ideas of globalization have existed for a long time. However, the necessary conditions for its planetary spread arose after the disappearance of the bipolar world and the fall of the Berlin Wall.

At the beginning of the 1990s many strategists, who were involved in the rise of optimism, called it the "New World Order". In 1992 three leading American strategists Ashton Carter, William Perry and John Steinbruner - spoke about the cooperation in security as the way for finding new approaches to the world peace: "Organizing principles like deterrence, nuclear stability and containment embodied the aspirations of the

\footnotetext{
${ }^{8}$ Cohen, Mihalka, op.cit., p. III (Preface)

${ }^{9}$ See: Held, D. McGrew, A. (eds): The Great Globalization debate: An Introduction, The Global Transformations Reader, Policy Press, Cambridge 2000
} 
Cold War... Cooperative Security is the corresponding principle for international security in the post-Cold War era." ${ }^{" 10}$ Cooperation in many areas of life became a new thing in international relations among recent political and military enemies, and this demonstrated a new period of peace. Everything looked like"... an escape from narrow Cold War "zerosum" strategies into the broad sunlit vistas of international peace and harmony. However, as is often the case in life, events have demonstrated that this early burst of optimism was, at best, premature."

People often fall into uncritical optimism because of their great desire that something would be as they would like it to be, especially after a long period of suffering and weak state of society and when that social misery ends in a radical way. After that great change people become engulfed in the wave of excessive hope and then everything looks simply like utopia even to the most careful and rational analysts: "... Francis Fukuyama went so far that he proclaimed these events 'the end of history'. Under this he included that the ideological discussion was practically over by the world triumph of the west liberal democracy..." ${ }^{12}$ In the moment of the great euphoria - triumph of the west forces and the fall of the USSR, it seemed to many people that it was finally the end of war and all dramatic conflicts belong to history. The moment of euphoria quickly passed - "war was back" in some parts of the world including parts of the former USSR and Yugoslavia. Some people think that in the insecure world the West sees its safety in its weapons, and in keeping "the world South under the Damocles' sword of military interventionism". ${ }^{13}$ Finally, global terrorism provoked a new kind of total world war by monstrous and spectacular acts in the USA, Madrid, London, Paris and Brussels. Instead of permanent and stable peace, the end of the Cold War brought growing militarism and the world divided into the explosions of internal conflicts and planetary military interventionism. The global war is depicted by the destruction of all material grounds of life, growing technological barbarism and readiness for the total destruction of society. It also has an extreme collective-psychological function: the creation of planetary fear. The world is still the place of deep-rooted inequalities and conflicts of interests, values and traditions.

\section{The Planetary Process of Networking}

Scholars of globalization can be divided into "hyper-globalists", "skeptics" and "transformationalists". For the first ones, globalization is the objective rule and an iron historical necessity: "... the event which is not the matter of will or the choice". ${ }^{14}$ The market and democracy became universally accepted, the unipolar world was made, dramatic fights, wars and conflicts are in the past, and a harmonious order in which the crucial human problems are solved prevails. ${ }^{15}$ However, this optimism conflicts with reality. In contrast

\footnotetext{
${ }^{10}$ Carter, A. Perry, W. Steinbruner, J.: A New Concept of Cooperative Security, The Brookings Institution Press, Washington 1993

${ }^{11}$ Cohen, Mihalka, op.cit., p. 3

${ }^{12}$ Heywood, op.cit., p. 30

${ }^{13}$ Holm, H.H. Sorensen, G.: Whose World Order, Uneven Globalization and the End of Cold War, Oxford 1995

${ }^{14}$ Friedman, T.: The Lexus and the Olive Tree, Understanding Globalization, Farrar Straus Giroux, New York 1999

${ }^{15}$ Fukuyama, F.: The End of the History and the Last Man, Hamish Hamilton, London 1992
} 
to this 'pink utopia' of life, all problems of the world ${ }^{16}$ are speaking for themselves and can be solved in the future by war or peace, cooperation or competition.

The existance of different nations, religions, traditions, interests, monopolies, values and morals is the destiny of all inhabitans of the planet. Globalization is the unavoidable historical course. It is the driving force of the world and all societies are confronted with a challenge of adaptation to the new world order.However, the path of modern society is open and uncertain; it can lead to either unification or fragmentation of the world, cooperation of civilization or conflicts of people. The advocates of globalization think that the last barrier to integration is localism, which should be destroyed through violence: "The crucial issue of the 21 st century in all the spaces will be the conflict... between the forces of the modern global economy and the forces of the atavitic tribalism....". Economy is the powerful driving force of globalization, but it is not its sole force. Globalization is an objective and planetary process ${ }^{18}$ of the wider net of correlation and interdependence... ${ }^{19}$ However, the future of the world is unpredictable. All the issues of mankind remain open and uncertain. The future days offer both fear and hope to the world. Historical developments can lead us to ecological and nuclear cataclysm, regional division of the world, a democratic world, and Orwell's "world society".

Richard Cohen thinks that this world is "dangerous and unstable" and that it can be a less risky place. "We need to build a system based upon mechanisms and institutions already in place, i.e., institutions that have proven themselves effective in providing relative peace, stability, and prosperity to nations and groups of nations in the last half of the $20^{\text {th }}$ century." ${ }^{20} \mathrm{He}$ thinks that the whole northern hemisphere can become the place of security and cooperation, and he carefully adds that: "the range... of the cooperation in security is probably limited" by the lack of "crucial values and...common geostrategic interests". Considering that after these optimistic words Russia and China performed common military manoeuvres, this project of Cohen becomes dubious. Let's think that this project of cooperation of the Southern hemisphere with all suspicions becomes reality, the justifiable question remains: will the world, which is separated into the North and South be a more secure place for all its inhabitants or will it remain economically, culturally, politically and religiously divided? This planetary problem of the future is clearly seen by some of the authors, who loudly pose the question: in the 21st century can the democratic society of the West control growing chaos along the southern strategic arc, which spreads from the Middle East to the southern and eastern coasts of Asia?

\footnotetext{
${ }^{16}$ The most important problems of the world should be stressed: demographic explosions and the hunger of people, the concentration of the people in small areas, all the forms of contamination, dirty technologies, and uncontrolled destruction of the natural resources of the Earth; global warming and ozone layer, earthquakes, droughts, typhoons, uncontrolled technologies from which there is the danger of the nuclear terrorism and the possibility of many kinds of epidemics. The future world, the world of global problems, has many problems to solve.

${ }^{17}$ Fromkin, D.: World Politics in the Twenty-First Century, World Policy Journal, No.10, 1993

${ }^{18}$ The closer connection of the world is caused by: technological-informatics revolution, the creation of global market, the closer connection between one event in one region to the other part of the planet, the rise of more powerful transnational and overnational economic powers and political institutions, the spreading of the same forms of life on the whole social space of the world.

${ }^{19}$ See: Keohane, R. Nye, J.: Globalization: What's New? What's Not? So What? Foreign Policy, Spring, 2000, pp. 104-119

${ }^{20}$ Cohen, Mihalka, op.cit., p. 4
} 
There are some famous authors who blame globalization because it is bringing risks and uncertainty, which Urlich Beck (1992) called 'the society of risk' marked by individualism and weakening of tradition, where uncertainty goes out of the familiar economic and social changes: "On overpopulated social...space... the explosion of violent cultural conflicts, the rise of tall fences, retreating into the towers of ethnic, nationalistic and religious local fundamentalism is possible...". ${ }^{21}$ Besides the optimists, who regard globalization as the increase of the welfare of the people, there are those who warn that: " 'americanization' ... of the world...and the extreme course of retrograde islamic fundamentalism... open the chapter of the dramatic conflicts, the wars of civilizations". ${ }^{22}$ There are signs that globalization is taking on a social, authoritarian character and that society is turning into 'the world risk society.'. ${ }^{23}$ Risk is a permanent feature of human existence through history, but it has never assumed such proportions until now." The 'Four Horsemen of the Apocalypse'- the danger of ecological cataclysm, the catastrophe made by nuclear, biological and chemical weapons; malign increase of poverty and the conflict of civilizations, global terrorism - are invading the planet". ${ }^{24}$ Much wisdom, capabilities and tolerance will be necessary for the statesmen of the biggest world nations to avoid all the traps and catastrophies, which the future time of challenges, risks and danger brings.

\section{War is Ahead of the Forces and Processes of Globalization}

There is a question of the relation between war and progress in human history. War was crucial for establishing all the great world empires: "... It is known that Napoleon's wars strongly promoted ... spreading European ideas, which caused scientific, technical and economical progress in the 19th century and materially united mankind..." ${ }^{25}$ Solovjov explains the relation between war and the spreading of peace in history and says: "In the whole peace issue the war was a necessary tool, and armed forces support. The key of the West success in creating global empires was in the "military revolution" which was the product of the industry, like the development of heavily armed ships for long sails and it announced the new place of Europe in the world." ${ }^{26}$ Well:"...Taken together, superior economic power, political unity and military sovereignty serve as the clearing of the unstoppable spreading of the West way of life in the recent two centuries" ${ }^{27}$ In a classical study: "The Rise and Fall of World Orders"... T. Knutsen ${ }^{28}$ shows "four waves of war" of the modern time:"..."lberian world order", under the hegemony of Spain in the 16th century, and the order of the 17th century, with the

\footnotetext{
${ }^{21}$ Commission on Global Governance, Our Global Neighbourhood: The Report of the Commission on Global Governance, Oxford University Press, Oxford 1995

${ }^{22}$ Huntington, S.: The Clash of Civilizations and the Remaking of World Order, Simon and Schuster, New York 1996

${ }^{23}$ Beck, U.: World Risk Society, Policy Press, Cambridge 1999

${ }^{24}$ Pečujlić, M.: Globalization, Belgrade 2002, pp. 21-22

${ }^{25}$ Kennedy, P.: The Rise and Fall of the Great Powers, Economic Change and Military Conflict from 1500 to 2000, Fontana Press, London 1989

${ }^{26}$ Solovjov, V.: The Selected Works, part 1, CID, Podgorica 1994, Chapter 18, The Idea of War, p. 438

${ }^{27}$ Giddens, A.: Sociology, Belgrade 2001, p. 55

${ }^{28}$ Knutsen, T.: The Rise and Fall of World Orders, Manchester University Press, 1999
} 
Netherlands on the top, the order "Pax Britanica" in the 18th and 19th century, and in the 20th century "Pax Americana" and... "the new world order" born on the ashes of the Cold War... Each of these orders... encompasses wider space of the world arena. The foundations of hegemony are manifold... technological, economic and military supremacy of the most powerful force of its time, but the legitimacy as the representative of universal values of its time.... A powerful army is always the significant guarantee to the most powerful forces to maintain world order, and that's why even today the global elite of power creates a planetary military force that will maintain the desired order. The militant wing of globalization asserts: "...It is not far when we will have to throw away every kind of sentimentality, to act from the position of the direct, physical force". ${ }^{29}$ To that supremacy of military force the other side is confronted by global terrorism, and that conflict was put to a much bigger level of risk and threats day in day out. Many times we wonder if that was the irreversible historical process which might lead to cataclysm and biological destruction of the human species. Our time is the time of power. Power and supremacy are magical words which move the world. Whatever we think about globalization, we must agree that planetary processes are leading the world to quick, deep, revolutionary and irreversible: economic, cultural, political, technicaltechnological and military changes in modern times.

Terrorism is a social phenomenon that can radically change and endanger the lives of people and many social communities. The possible use of nuclear weapons for total war and mass destruction terrorism have become fateful issues for mankind. There is the danger now that some terrorists could get nuclear, chemical and biological weapons. If the world wants to survive, it must cooperate despite many antagonisms, mistrust and military competition of the great powers. Today and tomorrow terrorism endangers the biological survival of the world, putting all the values of civilization at risk. The risk of life is put to its ultimate and irretrievable point. Many deep and complex causes of terrorism should be addressed, not only its fatal and obvious consequences. Analysts stress that in the future terrorist actions will include increasingly sophisticated forms of destruction and become more total because they will attack the most important national structures and vital commercial systems.

Modern wars affect the lives of all people. Due to the fact that the world has become interdependent, complex and thickly intertwined, a new way of thinking about war and peace is necessary. At the end of the Cold War international communication improved and economic exchange and travel between countries increased significantly. Unfortunately, terrorists also adapted to the new environment and effectively exploited its openness for their violent aims.

The global activities of terrorists are coordinated using human couriers, mobile and cable television, e-mails, internet and video tapes. International terrorist networks are equipped with modern technology which they use to exchange information, exercise, and plan and execute common activities. Terrorism is the big challenge to world peace "because terrorism became a global threat," but it cannot be rooted out using only military weapons. The war of terrorists is global and permanent because it is not the question whether the terrorists would attack, but: "When and where will that happen?" Terrorists declared war against the world, but the causes of terrorism are deep and far-reaching. They require the complete reshaping of the modern world into a place of cooperation, tolerance and better life for people. Terrorism relies on constant armed conflict. The

\footnotetext{
${ }^{29}$ Robinson, W.: Promoting Poliarchy, Globalization, US Intervention, and Hegemony, Cambridge University Press 1996
} 
historical means and character of human conflict are changing, but the presence of violence and competition among people, communities and countries persists. Planetary terrorism reflects Hobbes's thinking about human nature and war in his famous work "Leviathan" (1651). For Hobbes, the term "war" applies not only to times of "constant fight", but also "the whole period where the readiness to war is visible". The modern world requires much wisdom and good will, concession and understanding in order to build brighter, shared future for all.

\section{References}

[1] Beck, U.: World Risk Society, Policy Press, Cambridge 1999.

[2] Carter, A. Perry, W. Steinbruner, J.: A New Concept of Cooperative Security, The Brookings Institution Press, Washington 1993.

[3] Cohen, R. Mihalka, M.: Cooperative94

security: New Horizons for International Order, The Marshall Centre Papers, No. 3, GarmischPartenkirchen 2001.

[4] Commission on Global Governance, Our Global Neighbourhood: The Report of the Commission on Global Governance, Oxford University Press, Oxford 1995.

[5] Friedman, T.: The Lexus and the Olive Tree, Understanding Globalization, Farrar Straus Giroux, New York 1999.

[6] Fromkin, D.: World Politics in the Twenty-First Century, World Policy Journal, No.10, 1993.

[7] Fukuyama, F.: The End of the History and the Last Man, Hamish Hamilton, London 1992.

[8] Giddens, A.: Sociology, Belgrade 2001.

[9] Ham, P.V. Kugler, R.: Western Unity and the Transatlantic Security Challenge, The Marshall Centre Papers, No. 4, Garmisch-Partenkirchen 2002.

[10] Held, D. McGrew, A. Goldblatt, D. Perraton, J.: Global Transformation, Politics, Economics and Culture, Policy Press, Cambridge 1999.

[11] Held, D. McGrew, A. (eds): The Great Globalization debate: An Introduction, The Global Transformations Reader, Policy Press, Cambridge 2000.

[12] Heywood, A.: Politics, Second edition, Originally published by Palgrave Macmillan Ltd. Hampshire, New York 2002.

[13] Holm, H.H. Sorensen, G.: Whose World Order, Uneven Globalization and the End of Cold War, Oxford 1995.

[14] Huntington, S.: The Clash of Civilizations and the Remaking of World Order, Simon and Schuster, New York 1996.

[15] Kennedy, P.: The Rise and Fall of the Great Powers, Economic Change and Military Conflict from 1500 to 2000, Fontana Press, London 1989.

[16] Keohane, R. Nye, J.: Globalization: What's New? What's Not? So What? Foreign Policy, Spring, 2000, pp. 104-119.

[17] Knutsen, T.: The Rise and Fall of World Orders, Manchester University Press, 1999.

[18] Pečujlić, M.: Globalization, Belgrade 2002.

[19] Robinson, W.: Promoting Poliarchy, Globalization, US Intervention, and Hegemony, Cambridge University Press 1996.

[20] Solovjov, V.: The Selected Works, part 1, CID, Podgorica 1994. 